\title{
光変調器集積レーザー
}

\author{
青木 雅博 \\ 日立製作所中央研究所オプトエレクトロニクス研究部（†185-8601 東京都国分寺市東恋ケ窪1-280）
}

\section{Optical Modulator-Integrated Lasers}

\author{
Masahiro AOKI \\ Optoelectronics Research Department, Central Research Laboratory, HITACHI LTD., \\ 1-280, Higashi-koigakubo, Kokubunji, Tokyo,185-8601
}

(Received July 23, 2001)

\begin{abstract}
Modulator integrated lightsources are among the essential components of today's DWDM systems because of their compactness, high-speed operation, low frequency chirp and high cost efficiency. A recent progress in a $\mathrm{R} \& \mathrm{D}$ on modulator integrated lightsources is reviewed focussing on the technical issues and approaches.
\end{abstract}

Key Words: Dense wavelength division multiplexing, Modulator-integrated lasers, Optical fiber, Selective area MOVPE, Multiple quantum well structure

1. はじめに

光集積回路技術はその発案1,2) 以来, 20 年以上に渡り光工 レクトロニクスの高性能化, 低コスト化を主眼に研究開発 が進められてきた。この内, より沉用性が期待できるGaAs, InP系等の化合物半導体を用いた半導体光集積回路は,特に 光ファイバ通信の高性能化に向けた地道な研究が長年推 し進められてきたが, 残念ながら現状ではSi-LSIの大規模 集積化に比べるとまだ充分に成熟したとは言い難い状況 である. しかし, その数少ない実用成功例の一つは半導体 レーザー光源と光強度変調器をモノリシック一体化した 光変調器集積レーザーであろう。既に毎秒 $2.5 \sim 10$ ギガ ビットの光伝送光源として, 高密度波長多重通信 (DWDM; Dens Wavelength Division Multiplexing) システムにおける高 速光送信機の小型化, 経済化に大きく貢献している. 本稿 では,この光変調器集積レーザーの研究・開発に関し, 技 術的課題扮よび最新技術動向を関連する光伝送技術, 光半 導体集積技術を交え紹介する。

\section{2. 光変調器集積レーザーの研究背景, 経緯}

通常の光ファイバの伝送損失が最小となる $1.55 \mu \mathrm{m}$ 波長 帯で高速・長距離光伝送を行う場合, ファイバの損失制限 の他に, 変調に伴う光源のスペクトル広がり(チャーピン グ) とファイバ波長分散による伝送波形の歪みにより伝送 距離が大きく制限されることが示された3)。この克服に向 け, 半導体レーザーの直接変調方式に比ベチャーピングを 大幅に低減できる外部変調方式が検討されてきた. Fig. 1
は パララメータと呼ばれるチャーピング指数と最大ファイ バ伝送距離との関係を変調波形のガウス近似を用いて簡 易計算した結果である。通常ファイバの分散值 $17 \mathrm{ps} / \mathrm{km} /$ nmを仮定している。伝送速度にかかわらず直接変調方式 $(\alpha \doteqdot 2 \sim 8)$ に比べ外部変調方式 $(\alpha \doteqdot-1 \sim 1)$ では, 伝送距離 を大きく拡張できることがわかる。一方, 1989年頃から工 ルビウムをファイバコア部に添加し波長 $0.98 \mu \mathrm{m}$ まな $1.48 \mu \mathrm{m}$ の高出力光源で光励起するファイバインライン型 の光増幅器が爆発的に普及し始めた4)。これにより,ファ イバ損失はもはや伝送距離の制限主要因ではなくなり, ファイバ非線形性, 光増幅器の雑音特性と共に外部変調方

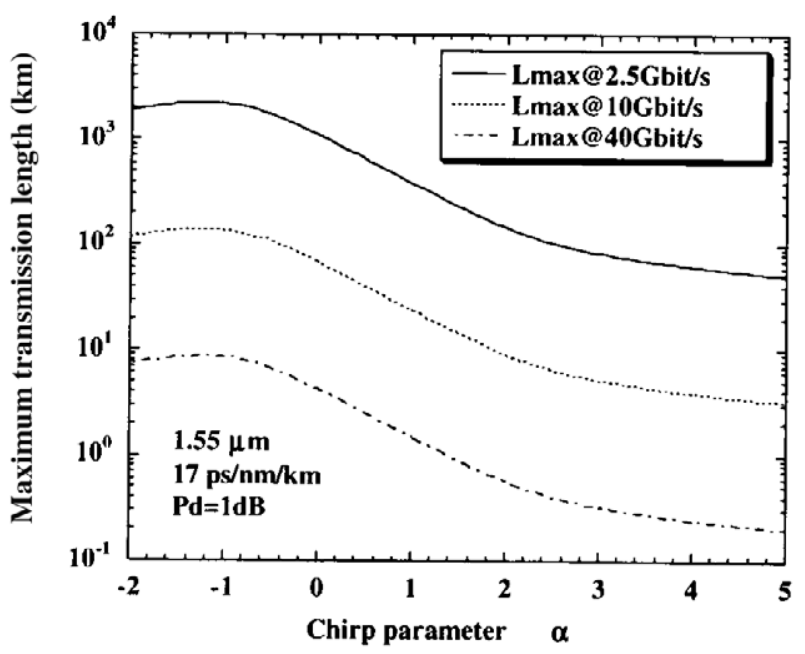

Fig. 1 Calculated maximum transmission distance as a function of chirp parameter $\alpha$. 
式とそのキーデバイスである光強度変調器の重要性がク ローズアップされるに至った。

現状広く実用化されている光強度変調器の構造は大き く分けて光吸収型と光干渉型 (マッハッェンダー (MZ; Mach Zehnder) 型) に大別できる。一方, 材料の観点からは 電気光学係数の大きなニオブ酸リチウム $\left(\mathrm{LiNbO}_{3}\right)$ とモノ リシック集積に適したInP系, GaAs系の化合物半導体に分 類される. 長距離ファイバ通信で重要な $1.55 \mu \mathrm{m}$ 波長帯 $(1.53 \sim 1.62 \mu \mathrm{m})$ で動作可能な半導体レーザーはInP系半導 体で実現するため, 現状では光変調器とレーザー光源との モノリシック集積化はInP系半導体に限定されている。一 方, 本論の対象ではないが, $\mathrm{LiNbO}_{3}$ や GaAs系のMZ変調器 にInP系のレーザー光源をハイブリッド集積により一体化 する試みも実用的観点から大变興味深い5,6).

1986年にKawamura等により吸収型光変調器と分布帰還 型レーザーの集積構造が初めて報告された7). 光変調器, 半導体レーザーは共にInP基板上の単一モード光導波路を 基本構造としており構造類似性から両者をモノリシック 集積化することは極自然なアプローチであった。この報 告を契機に特に吸収型光変調器集積レーザーの研究・開 発が活発してきた。

\section{3. 光変調器集積レーザーの技術課題とアプローチ}

光変調器集積レーザー実現の課題は3.1レーザー/変調器 導波路間の良好な光結合の実現, 3.2素子間クロストークの 抑制, 3.3光変調器の性能向上 (高速化, 駆動電圧低減, 低 チャーピング化), 3.4高出力化, そして3.5DWDM対応であ ろう。 以下これらの基本的技術課題とその検討状況につ いて詳述する。

\section{1 レーザー/変調器導波路間の良好な光結合}

レーザー/変調器を構成する $\mathrm{InP}$ 系結晶を媒質内の信号波 長 $($ 約 $0.5 \mu \mathrm{m})$ よりも十分に小さな作製精度で滑らかに結合 させ, レーザー光が効率良く変調器部へ導かれる構造を実 現することは第一の課題であった．現状ではFig. 2(a), (b) に示す2種の集積法が広く使われている. いずれも, 基板上 に形成した絶縁体マスクを用いて結晶成長領域を人為的 に制御する領域選択成長法に基づいた手法である. Fig. 2 (a)のバットジョイント (BJ; Butt-Joint) 法8) は, レーザー/変 調器に最適な結晶構造を別々の結晶成長で形成する理想 的な手法である。提案当初のBJ法は液相成長 (LPE; Liquid Phase Epitaxy)法で行われていたため, 絶縁体マスク端で必 然的に生じる突起状の異常成長が問題であった. しかし, 有機金属気相成長 (MOVPE; Metal Organic Vapor Phase Epitaxy) 法と適切な形状の絶縁体マスクを用いることで, この問題を解決できることが高性能分布反射 (DBR) 型 レーザー9) やBJ部をレーザー共振器内に含んだスポット拡 大導波路集積レーザーの実現により示された ${ }^{10)}$.さらに, ドライエッチング技術の導入により絶縁体マスク下のア ンダーカットをより精密に制御することで導波路結合部 の平坦性が向上された. 現在これらの技術が光変調器集 積レーザーへ展開されるに至っている11,12)。また, MOVPE

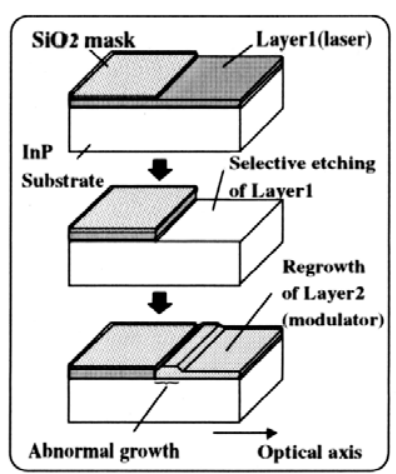

(a)

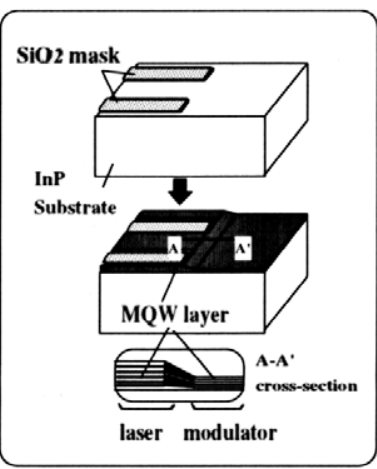

(b)
Fig. 2 Laser-modulator integration schemes based on (a) butt-joint coupling and (b) in-plane bandgap energy control by selective area growth.

に替わり,絶縁体マスク近傍の平坦性に優れる有機金属分 子線結晶成長法 (MOMBE; Metal Organic Molecular Beam Epitaxy)や化学ビーム結晶成長 (CBE; Chemical Beam Epitaxy)を用いた改善例13,14) が報告されている。

Fig. 2(b) に示す基板面内バンドギャップ制御法15,16)は, 選択成長におけるマスク端近傍での成長速度増大を積極 的に利用した一括集積技術である. Fig. 2(b)に示すよう に, 一対の絶縁体マスクを導波路光軸と平行な方向に形成 した基板上に量子井戸 (QW; Multiple Quantum Well) 構造を MOVPE法で選択成長することにより実現される。本手法 では, 従来複数回の結晶成長で形成してきた集積構造が1回 の結晶成長で実現できるため, 作製法が簡略化する点が最 大の長所である。さらに, 素子間の結合部が滑らかなテー パ状になるため, 素子間の光結合効率がほぼ100\%である。 一方, 集積する全ての要素デバイスを同じ構造のQW導波 路で構成する必要があるため一般的にはデバイス個々の 最適設計の観点では難が有る。しかし, 特に吸収型光変調 器とレーザー光源の集積化の場合には本手法は多いに威 力を発揮する.デバイスの動作原理 (吸収型変調器; 光吸 収とフォトキャリアのQW外への排出, レーザー；QWへの キャリア注入と光放出) が互いに酷似しており, その結果 各々に最適なQW構造も似通ったものとなるためである。 本手法に拠れば, 光変調器集積レーザーを従来の単体レー ザーとほぼ同様のウェハ工程で作製でき, 2.5 10 Gbit/s用 途に広く実用化されている。

\section{2 素子間クロストークの抑制}

変調器とレーザーが数十 $\mu \mathrm{m}$ 程度の間隔で同一基板上に 隣接形成された光変調器集積レーザーでは, 素子間のクロ ストークを十分に考慮した設計が不可欠である。一般に クロストークの物理要因として, 電気, 光および熱が考え られるが,この内応答速度の遅い熱クロストークの影響は 本質的でない場合が殆どである。電気クロストークにつ いては, レーザーは順方向バイアス, 変調器は逆方向バイ アスにて動作することから十分な電気的分離が必須であ る. 現状の光集積素子技術では, $n$ 型基板を共通接地とし, 高抵抗半導体層による埋め込みへテロ (BH; Buried Hetero) 構造やリッジ構造を導波路に使用する場合が多い。この 
場合, 素子間は比較的抵抗率の高いp型クラッド層で電気接 続される。この結果, 電気クロストークを抑制するに十分 な数 $10 \mathrm{k} \Omega$ 程度の分離抵抗值を比較的容易に得ることがで きる。これに対し, 光クロストークはチャーピング特性に 極めて重大な悪影響を与えることが多く, 適切な光クロス トーク抑制技術が必要とされる17-19). 外部変調方式では一 般に電圧印加に伴う変調器材料の屈折率変動により位相 チャーピングが生じる20). 一方, 光変調器集積レーザーで は, この位相チャーピングに加え高速変調光の極一部が変 調器前端面で反射しレーザー部に逆戻りすることによっ てレーザー部にチャーピングが誘発される ${ }^{17,18)}$.このいわ ゆる戻り光チャーピングは直接変調におけるチャーピン グ量に比べればわずかではあるが, ギガビット級の伝送速 度で数百 $\mathrm{km}$ 以上の長距離ファイバ伝送をする場合, 受信後 の信号品質に無視できない悪影響を及ぼす．Fig. 3は戻り 光チャープによる受信信号波形劣化のシミュレーション 例である21). 伝送速度 $2.5 \mathrm{Gbit} / \mathrm{s}$, 通常分散ファイバを仮定 $し$, 変調器前端面反射率 $\left(R_{\mathrm{f}}\right)$ を変化させた場合のファイバ 伝送後の受信波形を計算している。伝送前は $R_{\mathrm{f}} に$ 依存せず 明瞭なアイ開口が見られるが, 特に $R_{\mathrm{f}}$ が $0.5 \%$ 以上の場合に は伝送距離の増大に従い著しい波形劣化が起こってい る。この例からも明らかなように, $R_{\mathrm{f}}$ の低減は変調器集積 レーザーの低チャーピング動作に必須である．現在では, 電子ビーム蒸着法, イオンビームスパッタリング法等の膜

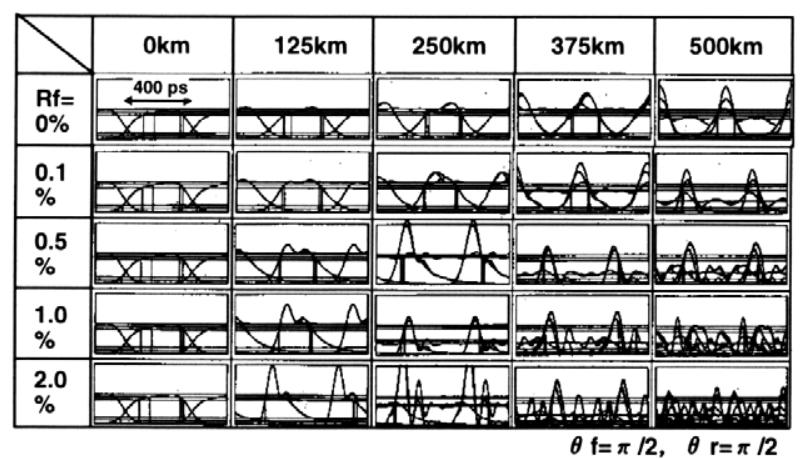

Fig. 3 Calculated transmitted eye diagrams with a signal rate of $2.5 \mathrm{Gbit} / \mathrm{s}$. Calculation is with various amounts of modulator facet reflevtivity.

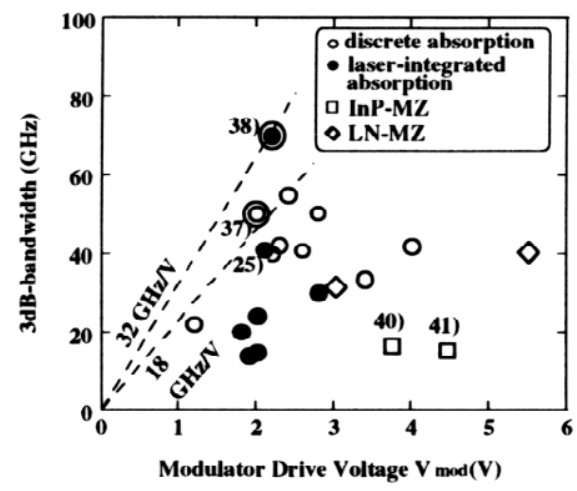

(a)
厚制御性の極めて優れた誘電体多層膜技術による低反射 膜の形成や導波路を端面近傍の結晶内側で終端させ端面 部での光反射を抑制したいわゆる空構造22)の採用により, 実効的な $R_{\mathrm{f}}$ 值とし0.01\%程度以下が得られるようになって きており戻り光チャーピングを十分抑制できる技術が確 立されてきた。 $R_{\mathrm{f}}$ 值の低減以外にも, レーザー部のダンピ ングパラメータ (非線形利得飽和係数) を大きく設計するこ とにより,レーザー部の緩和振動に伴うチャーピングを低 減する手法も提案されている23).

\section{3 光変調器の性能向上; 高速化, 低駆動電圧化, 低 チャーピング化}

半導体光変調器で通常使われてきた集中定数 (LE: Lumped Element) 型電極構造における動作速度は基本的に 素子容量により決定される. 従って, 変調器の高速化には, 変調器導波路長の短縮や光吸収層を厚膜化するなどして 容量低減を図る手法が一般的である。しかし, 変調器長の 短縮は消光比 (オン・オフ比) を低下させる他, 活性層厚の 増大は活性層領域の電界強度低下を通じて駆動電圧や $\alpha$ パ ラメー夕を増大させる。このように, 高速動作と低電圧 · 低チャーピング動作は互いにトレード・オフの関係にあ る.

Fig. 4(a) はこれまでに報告された種々の導波路型光強度 変調器について変調帯域と駆動電圧との関係をまとめた ものである. 図は所定の消光比を得るのに必要な変調器 駆動電圧を横軸とし, 光強度基準での $3 \mathrm{~dB}$ 変調帯域をプ ロットしたものである。ここで吸収型変調器に対しては $15 \mathrm{~dB}$ のC消光比が得られる電圧を, MZ変調器に対しては 位相反転電圧 $\left(V_{\pi}\right)$ をそれぞれ駆動電圧とした。低電圧・高 速動作の観点から $\mathrm{GHz} / \mathrm{V}$ の単位を持つグラフの傾きが重要 な性能指数である. 図中, 白抜きのプロットは単体光変調 器を, 塗りつぶしプロットはレーザーをモノリシック集積 化した光変調器のデータである. 吸収型光変調器の場合, 主に光吸収層の層構造を最適化することにより変調帯域 $50 \mathrm{GHz}$, 駆動電圧 $3 \mathrm{VW下}(18 \mathrm{GHz} / \mathrm{V})$ 程度が得られるよう になっており, 全IC化した化合物半導体ドライバによる直 接駆動を用いた40 Gbit/s動作が実現されている24). ま た, 極最近レーザーを集積化した素子においても同等の性

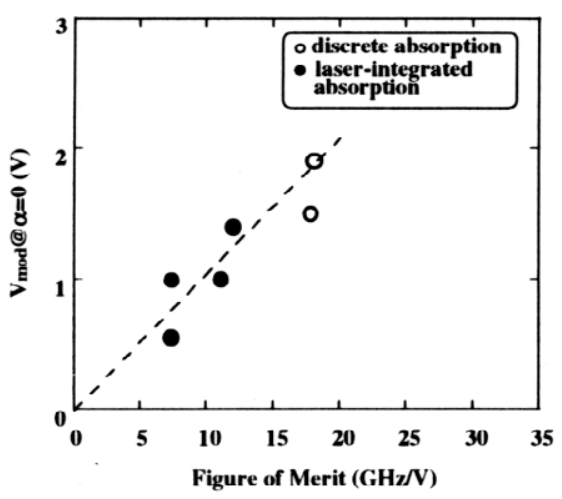

(b)

Fig. 4 (a) Figure of merit (FOM) of reported optical modulators. (b) The relationship between FOM and chirp parameter $\alpha$. 
能が報告されるに至っている25).

続いて, 低チャーピング化について議論する. 変調器に レーザーを集積したことにより生じる戻り光チャーピン グを十分に抑制した後には, 変調器自体のチャーピング特 性が議論の中心となる. 文献20)にも示されているように, MZ型光変調器のチャーピングは変調手法に依存し, - 1 +1 程度に人為制御できる. 一方, 吸収型光変調器では Kraemers-Krönigの関係式で記述される媒質の吸収变化と 屈折率変化の比で決定され, 動作波長や光吸収層の電界強 度に依存する．多重量子井戸構造を有する吸収型光変調 器の消光特性とチャーピング特性の一例をFig. 5に示す. $\alpha$ パラメー夕 (実線) は, 変調器動作電圧に大きく依存し, 低 電圧領域では正值 (レッドチャーピング) を示すが, 動作電 圧の増大に従い徐々に減少し, 零を経過後, 深い電圧領域 では負值 (ブルーチャーピング) に転じる。これは, 電界印 加に伴う屈折率の変化の符号が变わるためである. 実際 のディジタル変調では, $10 \mathrm{~dB}$ 程度以上の消光比が確保され るように変調器に印加する電圧信号の範囲を調整するが, 多くの場合光のオンレベルではレッドチャーピング, 光の オフレベルではブルーチャーピングに設定される. Fig. 1 に示した, 通常ファイバの線形分散領域では, 適度なブルー チャーピングにおいて $(\alpha=-1 \sim 0)$ 伝送距離は最大とな る.これまでに, 光のオンレベル電圧を深く設定し, ディ ジタル変調時の平均的な $\alpha$ 值を低減することにより伝送距 離を拡大した例が報告されている26). しかし, 変調信号強 度が減少するデメリットから本手法ではオンレベル電圧 の調整が極狭い範囲に制限される。本質的な改善として は, Fig. 5の $\alpha-V_{\text {mod }}$ 曲線をできる限り左下方向にシフトさせ, 低電圧動作時にも $\alpha$ 值を低減する構造が望ましい27,28). Matsuda等は多重量井戸の価電子帯構造と $\alpha$ 值との関係に 着目し, 価電子帯バンドオフセット量を適正化することに より低電圧動作時から負の $\alpha$ 值を有する変調器集積レー ザーを実現している28).

Fig. 4(b) はFig. 4 (a) と同様, 既報の集中定数電極を有す る吸収型光変調器について前述の性能指数と $\alpha$ 值が符号反

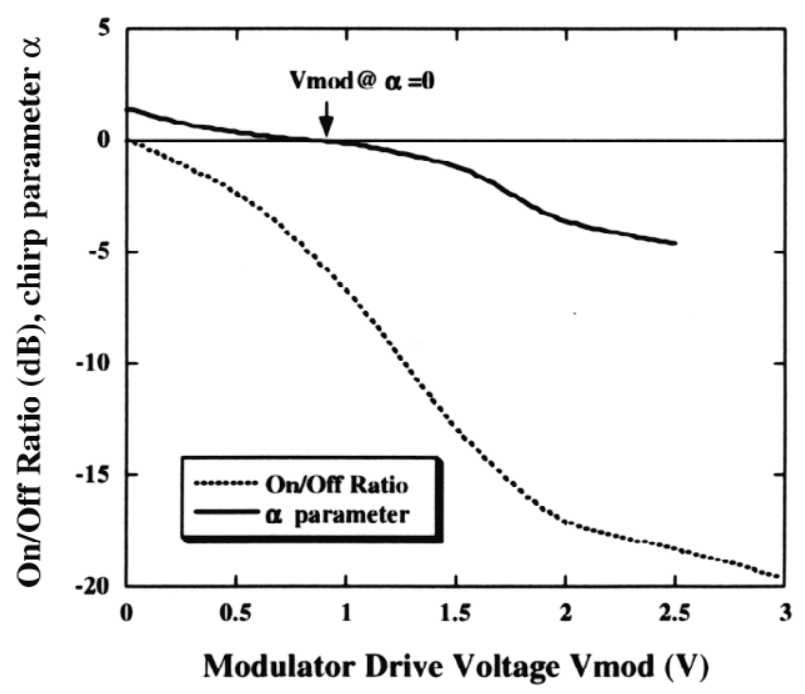

Fig. 5 Modulator voltage dependence of chirp parameter $\alpha$ and on/off ratio.
転する電圧值との関係をプロットしたものである．報告 デー夕はほぼ一直線上に分布しており, 光変調器の性能指 数と低チャーピング化とのトレードオフ関係が良く理解 される。

\section{4 高出力化}

一般に, 光変調器集積レーザーの最大光出力は, (a)レー ザー光出力特性, (b) レーザー/変調器間光結合特性, (c) 変 調器透過損失および (d) 変調器の高光入力耐性の 4 点で決定 される. 最終的な光モジュールの観点からは, (e)ファイバ への光結合特性がこれに加わる。これらの中で, (a), (b) および (e)はそれぞれInP系歪量子井戸レーザー技術, 既述 の光導波路結晶結合技術, 非球面レンズ結合技術の着実な 進展により主要な制約事項ではなくなりつつある。一方, 光吸収とフォトキャリアの排出を動作原理とする吸収型 光変調器では (c)および (d) は出力特性を決定する重要な要 因である. 特に $(\mathrm{d})$ の光入力耐性は, 最終的に変調器が動作 し得る光入力レベルの上限を決定するため, これまでに 様々な検討がなされてきた26,29-34). 変調器の光吸収層で は電界印加による光吸収の増加に伴いフォトキャリア(電 子・正孔)が大量生成される。これらは, フォトカレント (光電流)としてそれぞれn型, $\mathrm{p}$ 型半導体層へ有限の時間 (キャリアエスケープ時間)で排出される。したがって, 定 常状態では光吸収量とキャリアエスケープ時間の大小に 応じ吸収層とその近傍にフォトキャリアが蓄積(パイル アップ)される。このパイルアップキャリアは, 印加電界を 打ち消す方向にスクリーニング電界を生じさせるため, 光 変調器の動作に種々の影響を及ぼす。ささらに, 量子井戸変 調器ではフォトキャリアが数多くのへテロ障壁を通過す るためにさらにキャリア(特に有効質量の大きな正孔)の熱 放出過程の影響が加わる。これまでに,キャリアエスケー プ時間を低減する手法として, 浅い量子井戸の適用 ${ }^{32,33)}$, 伸 張格子歪を有する障壁層の導入による正孔有効質量の低 減 ${ }^{34)}$, 傾斜型へテロ障壁 (グレーデッド障壁)の適用26)によ る光入力耐性の向上が検討されている。これらの改善の 結果, 現状では通常の光送信機の出力レベルである $2 \mathrm{~mW}$ $(+3 \mathrm{dBm})$ 程度のファイバ出力が $10 \mathrm{Gbit} / \mathrm{s}$ 動作で実現可能 となっている。しかしながら, 吸収型光変調器ではその動 作原理が光吸収に依らないMZ型変調器に比べ特に高速化 と高出力化のトレードオフがより厳しい状況にあること は否めない事実である。特に40 Gbit/s以上の高速化の場 合, 容量低減に不可欠となる吸収層体積の低減とこれに伴 う光吸収密度の増大が素子設計を困難にすることが予想 される. 吸収型光変調器の高速性, 低電圧駆動性を生かし つつ高出力化を図ることが今後さらなる高性能化に向け た課題である.

\subsection{DWDM対応：波長選択, 波長可変, 波長リファレ ンス}

最後にDWDM対応に関する課題に触れる. DWDM用光 変調器集積レーザーに対する技術課題は主にレーザー部 の波長特性と光変調器の波長依存性に関するものであり, 波長制御性, 波長選択 - 可変構造, 波長安定化が議論の中 
心である。ここでは技術詳細は本特集号の解説 2 に譲り, 変 調器集積化に伴う課題を述べるに留める. 固定波長用途 の光変調器集積レーザーの波長制御性に関しては, 通常の DWDM用レーザーと同様の技術が用いられている。すな わち, レーザー動作温度の微調により, 発振波長を波長チャ ンネル基準であるITUグリッド上に合わせ込む波長調整技 術である。この場合, レーザーと光変調器の温度特性が異 なるため, 光変調器の狭い動作温度範囲に波長可変域が制 限されることが, 残念ながら光変調器集積レーザーの大き な短所である. 光変調器結晶のバンドギャップ波長と信 号光波長は温度上昇に伴い共に長波長化するが, バンド ギャップ波長の温度係数が信号光波長のそれより6〜8倍 大きいため両者の差である離調量が温度によって大きく 変化することが本質的理由である。これに対し, 吸収型光 変調器の離調量依存性を低減する手法14)や, レーザー部を 局所加熱する手法35)等が報告されているほか, 波長可変分 布反射(DBR) 型レーザーの採用による電気的波長チュー ニングが検討されている36).

\section{4. 高性能光変調器集積レーザー}

前節で議論した光変調器集積レーザーの技術課題の多 くは素子設計, プロセス技術の進展により解決されてい る. 本節では,ここ数年の間に報告されたより高性能な光 変調器集積レーザーを紹介する。

\section{$4.140 \mathrm{Gbit} / \mathrm{s}$ 変調器集積レーザー}

インターネットの爆発的な普及に伴い, 単位チャンネル 当りの伝送容量を $40 \mathrm{Gbit} / \mathrm{s}$ に拡大した高速DWDM伝送技術 への期待が高まっている. Fig. 6 は40 Gbit/sで動作可能な 吸収型変調器集積レーザーの報告例である ${ }^{25)}$. 高速化設 計として変調器長を $100 \mu \mathrm{m}$ に短縮すると共に前述の変調 器高出力耐性を考慮した設計を施した結果, 数mWの高出 力下で41 GHzの広帯域を実現している。また, - $1.6 \mathrm{dBm}$ の

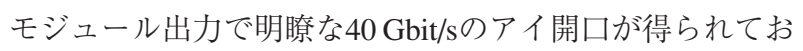
り完成度は高い.今後の実用化動向が注目される。

\section{2 進行波 $(\mathrm{TW})$ 型電極による高速化}

前節で議論したように集中定数 (LE: Lumped Element) 型 光変調器での高速性は容量律速である。一方, 進行波 (TW: Travelling Wave) 型電極を有する構造では光導波路近傍に 形成された電極がマイクロ波伝送路として取り扱われ, 変 調器駆動信号は電極上を進行波の形で光信号と並走して 伝搬する. ここで, 光波の進行速度 $v_{\mathrm{opt}}$ と変調器駆動信号の 伝搬速度 $v_{\mathrm{ele}}$ とをできる限り一致させることで変調器の素 子容量に依存しない高速動作を実現することが可能とな る. 一般に, $\mathrm{TW}$ 型変調器の導波路材料としては, 主に光変 調器用途の二オブ酸リチウムや光変調器や光検出器用途 のInP系, GaAs系などの化合物半導体が検討されている. この内, 化合物半導体を用いた進行波素子に関しては主に 電気信号と光信号間の屈折率 (比誘電率)の差が大きいため 一般には位相整合条件 $\left(v_{\mathrm{opt}}=v_{\mathrm{ele}}\right)$ を完全に満たすことは困 難である。しかし, 電気・光信号間の作用長となる変調器

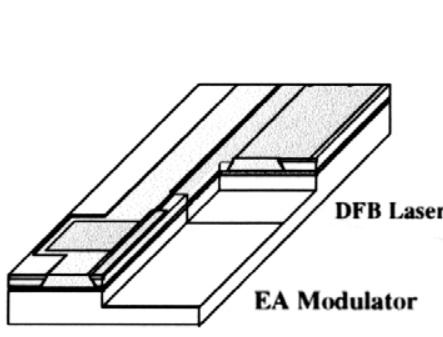

(a)

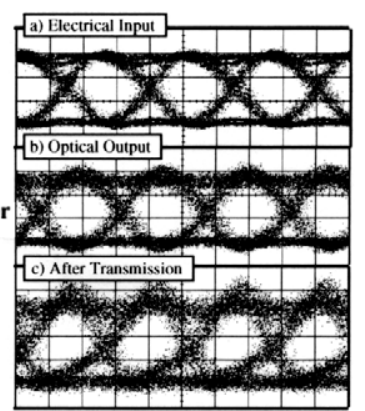

(b) 10ps/div.

Fig. 6 The device structure and $40 \mathrm{Gbit} / \mathrm{s}$ eyes for an integrated lumped element modulator/laser. ${ }^{25}$ )

長が300 $\mu \mathrm{m}$ 程度以下と短い吸収型変調器の場合は比較的位 相不整合による高速性の劣化が少ないことが示された ${ }^{37)}$.

Fig. 7はこの原理に基づいたTW型光変調器集積レーザーの 最初の報告例である ${ }^{38)}$. Fig. 4(a) にプロットしているよう に, 光 $3 \mathrm{~dB}$ 変調帯域 $70 \mathrm{GHz}$, 駆動電圧 $2.2 \mathrm{~V}$ が得られており, 性能指数は $32 \mathrm{GHz} / \mathrm{V}$ と従来值を大きく上回った. Fig. 4(b) に示したように変調器の駆動電圧・変調帯域に関する性 能指数と低チャーピング化のトレードオフを打破する一 技術として今後の進展が楽しみである.

4.3 マッハッェンダー $(\mathrm{MZ})$ 型光変調器集積レーザー $\mathrm{MZ}$ 型光変調器は特にニオブ酸リチウム $\left(\mathrm{LiNbO}_{3}\right)$ 材料を 用いた単体デバイスが広く実用に至っている。これに対 しレーザーのモノリッシック集積の観点から, InP基板上に $\operatorname{InGaAs}(\mathrm{P})$ やInGaAlAs材料の位相変調器を MZ干渉導波路 中に配置した構成の半導体MZ変調器の研究がなされてい $3^{39-41)}$. 通常, 半導体の電界印加による吸収率変化に比べ ると遥かに小さい屈折率変化を少しでも増大させるため に, 井戸層を厚膜化した多周期量子井戸構造を導入し位相 変調効率の増大を量る設計がなされているが, Fig. 4(a)に 示すように光変調器の性能指数の観点では吸収型に比べ ると大きく劣っているのが現状である. 文献42)の例では, レーザー光源の集積化も達成され既に, $2.5 \sim 10 \mathrm{Gbit} / \mathrm{s}$ 用の DWDM光源として実用化されている. MZ型光変調器では 変調器の駆動条件を制御することによりチャーピング量 をフレキシブルに可変できること, 動作波長に対するトレ ランスが大きいことが吸収型光変調器と比べた場合の最 大の特長である. 半導体MZ光変調器の性能指数を向上す る手法として前述のTW型電極を導入した例 43,44$)$ が報告さ

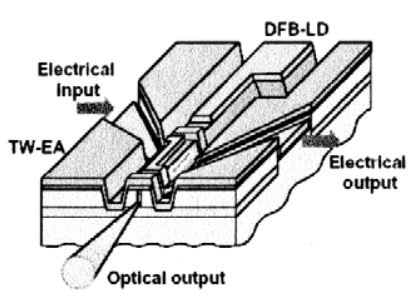

(a)

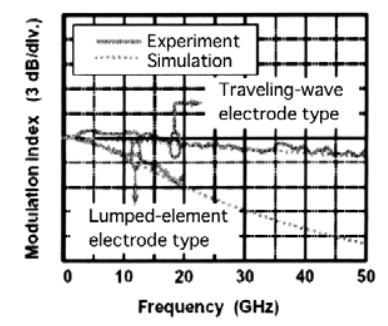

(b)
Fig. 7 The device structure and high-speed characteristics for an integrated travelling-wave modulator/laser. ${ }^{38)}$ 
れており,今後の進展が注目される。

\subsection{DWDM対応光変調器集積レーザー}

波長選択・可変機能を搭載した光変調器集積レーザー はDWDMの高性能化・経済化に不可欠となりつつある. 既に, 多波長レーザーアレイに合波器, 損失補償光増幅器, 吸収型光変調器をモノリシック集積化した波長選択型変 調器集積レーザー45) や波長可変DBRレーザーに損失補償 光増幅器, 吸収型光変調器をモノリシック集積化した波長 可変型変調器集積レーザー36) が報告されており, $50 \mathrm{GHz}$ の ITUグリッドを $20 \mathrm{ch}$ 程度以上カバーするデバイスが実現さ れている。また, 特に数十 $\mathrm{nm}$ に渡る広範囲波長帯域で動作 する素子を一枚の基板上に一括作製する技術が報告され ている46)。一方, ITUグリッドに合わせ込んだレーザー波 長を長期的に安定化させる手法として, 波長リファレンス となる誘電体エタロンフィルタをマイクロオプティクス 技術を用いて搭載し, 波長分別器を光モジュールの内部に 作り达んだ波長分別器内蔵型モジュール47,48) が報告されて おり,実DWDMシステムへの展開が確実に進行している。

\section{5. まとめ}

光変調器集積レーザーの研究開発の状況に関し簡単に 紹介した。 小型化, 低チャーピング化, 高速化, 低電力化, 波 長制御と経済性が両立可能な本デバイスは2.5〜10 Gbit/s DWDM伝送用光源として重要な役割を担うにまで技術は 進展してきた。 $40 \mathrm{Gbit} / \mathrm{s} へ の$ 実用展開も近い将来実現する だろう。今後は幹線伝送系のみならず, 高速メトロ系等へ の展開も含め一層発展することを期待したい.

\section{参考文献}

1) S. E. Miller: Bell Syst. Tech. J. 48 (1969) 2059.

2) Y. Suematsu: Technical Digest of IOOC '77, B-1 (1977) 185

3) F. Koyama and Y. Suematsu: IEEE J. Quantum Electron. QE-21 (1985) 292

4) For example, Special issue on optical amplifier, J. Lightwave Technol. 9 (1991) 145.

5) B. Ade, P. Dunn, T. Munks, and P. Sanders: Technical Digest of OECC' $98,14 \mathrm{~B} 3-5$ (1998) 140.

6) R. A. Griffin, R. G. Walker, R. I. Johnstone, R. Harris, N. M. B. Perney, N. D. Whitbread, T. Widdowson, and P. Harper: Technical Digest of OFC '01 (2001) PD-15.

7) Y. Kawamura, K. Wakita, Y. Yoshikuni, Y. Itaya, and H. Asahi: Electron. Lett. 22 (1986) 242.

8) Y. Abe, K. Kishino, Y. Suematsu, and S. Arai: Electron. Lett. 17 (1981) 945

9) Y. Tohmori, F. Kano, M. Oishi, Y. Kondo, M. Nakao, and K. Oe: Electron. Lett. 24 (1988) 1481.

10) H. Oohashi, M. Fukuda, Y. Kondo, M. Yamamoto, Y. Kadota, F. Ichikawa, Y. Kawaguchi, K. Kishi, Y. Sakai, M. Yanagisawa, S. Ishibashi, F. Hanawa, T. Hashimoto, Y. Tohmori, K. Yokoyama, Y. Itaya, and H. Toba: Technical Digest of ECOC '97 (1997) 351

11) K. Morito, R. Sahara, K. Sato, Y. Kotaki, and H. Soda: Electron. Lett. 31 (1995) 975.

12) H. Takeuchi, K. Tsuzuki, K. Sato, M. Yamamoto, Y. Itaya, A. Sano, M. Yoneyama, and T. Otsuji: IEEE Selected Topics in Quantum Electron. 3 (1997) 336

13) H. Kunzel, S. Ebert, R. Gibis, P. Harde, R. Kaiser, H. Kizuki, and S. Malchow, Indium Phosphide and Related Materials (1998) 571.

14) H. Debregeas-Sillard, P. Doussiere, A. Bodere, P. Rael, O. Legouezigou, G. Michaud, F. Gaborit, S. Gauchard, and F. Brillouet:
IEEE Photon. Technol. Lett. 11 (1999) 1485.

15) T. Kato, T. Sasaki, N. Kida, K. Komatsu, and I. Mito: Technical Digest of ECOC '91 (1991) WeB7-2.

16) M. Aoki, H. Sano, M. Suzuki, M. Takahashi, K. Uomi, and A. Takai: Electron. Lett. 27 (1991) 2138.

17) 松本研司, 粕川 秋彦, 未松安晴: 第29回応用物理学会学術講 演会予稿集 (1982) 3a-H-8.

18) H. Soda, K. Sato, H. Sudo, S. Takeuchi, and H. Ishikawa: Technical Digest of ECOC' 91 (1991) WeB7-2

19）青木 雅博, 佐野博久, 魚見 和久, 高井 厚志: 第39回応用物理 学会学術講演会予稿集 (1992) 30a-SF-12

20) F. Koyama and K. Iga: J. Lightwave Technol. LT-6 (1988) 87.

21) M. Aoki, S. Takashima, Y. Fujiwara, and S. Aoki: IEEE Photon. Technol. Lett. 9 (1997) 380.

22) K. Utaka, S. Akiba, K. Sakai, and Y. Matsushima: IEEE J. Quantum Electron. 20 (1984) 236.

23) Y. Kotaki and H. Soda: Technical Digest of ECOC '93 (1993) WeP8.6.

24) K. Ishikawa, K. Watanabe, H. Suzuki, R. Takeyari, T. Tanoue, T. Masuda, R. Hayami, K. Washio, H. Chiba, K. Ohnaka, K. Hirata, and T. Harada: Technical Digest of ECOC 'OO (2000) paper 2.3.4.

25) H. Kawanishi, Y. Yamauchi, N. Mineo, Y. Shibuya, H. Murai, K. Yamada, and H. Wada: Technical Digest of OFC '01 (2001) MJ3

26) K. Morito, R. Sahara, K. Sato, Y. Kotaki, and H. Soda: Electron. Lett. 31 (1995) 976.

27) T. Yamanaka, K. Wakita, and K. Yokayama: Appl. Phys. Lett. 68 (1996) 3114.

28) M. Matsuda, K. Morito, K. Yamaji, T. Fujii, and Y. Kotaki: IEEE Photon. Technol. Lett. 10 (1998) 364.

29) U. Koren, B. I. Miller, T. L. Koch, G. Eisenstein, R. S. Tucker, I. Bar-Joseph, and D. S. Chemla: Appl. Phys. Lett. 51 (1987) 1132.

30) M. Fox, D. A. B. Miller, G. Livescu, J. E. Cunningham, J. E. Henry, and W. Y. Jan: J. Quantum Electron. 27 (1991) 2281.

31) T. H. Wood, J. Z. Pastalan, C. A. Burrus, Jun., B. C. Johnson, B. I. Miller, J. L. Demiguel, U. Koren, and M. G. Young: Appl. Phys. Lett. 57 (1990) 1081.

32) T. H. Wood, T. Y. Chang, J. Z. Pastalan, C. A. Burrus, Jun., N. J. Sauer, and B. C. Johnson: Electron. Lett. 27 (1991) 257.

33) K. W. Goossen, L. M. F. Chirovsky, R. A. Morgan, J. E. Cunningham, and W. Y. Jan: Photon. Technol. Lett. 3 (1991) 448

34) R. Sahara, K. Morito, and H. Soda: Electron. Lett. 30 (1994) 698

35) M. Aoki, A. Ohishi, M. Shirai, R. Kaneko, H. Kuwano, and S. Tsuji: Technical Digest of ISLC 'OO (2000) TuB2.

36) J. E. Johnson, L. J.-P. Ketelsen, J. M. Geary, F. S. Walters, J. M. Freund, M. S. Hybertsen, K. G. Glogovsky, C. W. Lentz, W. A Asous, P. Parayanthal, T. L. Koch, and R. L. Hartman: Technical Digest of OFC' 01 (2001) TuB3.

37) K. Kawano, M. Kohtoku, M. Ueki, T. Iyo, S. Kondoh, Y. Noguchi, and Y. Hasumi: Electron. Lett. 33 (1997) 1580.

38) Y. Akage, K. Kawano, S. Oku, R. Iga, H. Okamoto, Y.Miyamoto, and H. Takeuchi: Technical Digest of ISLC '00 (2000) PD1.

39) J. E. Zucker, K. L. Jones, B. I. Miller, and U. Koren: Photon. Technol. Lett. 2 (1990) 32

40) H. Sano, H. Inoue, S. Tsuji, and K. Ishida: Technical Digest of OFC '92 (1992) ThG4.

$41)$ C. Rolland, R. S. Moore, F. Shepherd, and G. Hillier: Electron. Lett. 29 (1993) 471.

42) C. Rolland: Technical Digest of OFC '98 (1998) ThH1.

43) R. G. Walker: IEEE J. Quantum Electron. 27 (1991) 654

44) L. Moerl, D. Hoffmann, K. Matzen, C. Bornholdt, G. G. Mekonnen, and F. Reier: Technical Digest of OPRM '99 (1999) WeA1-3

45) K. Kudo, K. Yashiki, T. Sasaki, Y. Yokoyama, K. Hamamoto, T Morimoto, and M. Yamaguchi: Photon. Technol. Lett. 12 (2000) 242.

46) Y. Furushima, Y. Sakata, Y. Inomoto, M. Ishizaka, J. Shimizu, K. Komatsu, K. Kudo, K. Yashiki, Y. Yokoyama, M. Yamaguchi, Y. Muroya, T. Sasaki, M. Ushirozawa, T. Kosugi, and H. Tanaka: Technical Digest of ECOC 'OO (2000) paper 3.3.4.

47) D. M. Adams, C. Gamache, R. Finlay, M. Cyr, K. M. Burt, J. Evans,E. Jamroz, S. Wallace, I. Woods, L. Doran, P. Ayliffe, D Goodchild, and C. Rogers: Electron. Lett. 37 (2001) 691.

48) K. Tatsuno, M. Shirai, H. Furuichi, K. Kuroguchi, N. Baba, H. Kuwano, Y. Iwafuji, and A. Murata: Technical Digest of OFC '01 (2001) TuB5. 